\title{
Pengaruh Kompetensi dan Job Deskripsi ( Tugas Pokok dan Fungsi ) Terhadap Kinerja Karyawan Di PT. Arghaniaga Pancatunggal
}

\author{
Larsen Barasa $^{1}$, Sari Kusumaningrum ${ }^{2}$, Yola Miranda ${ }^{3}$ \\ 1, 2, 3 Prodi Ketatalaksanaan Angkutan Laut dan Kepelabuhanan \\ Sekolah Tinggi Ilmu Pelayaran, Jakarta \\ Jl. Marunda Makmur No. 1 Cilincing, Jakarta Utara. Jakarta 14150
}

\begin{abstract}
Abstrak
PT. Arghaniaga Pancatunggal merupakan perusahaan pemasok BBM seperti high speed diesel (HSD) dan muel fuel oil (MFO). Berdasarkan data, permasalahan yang ada membahas tentang kompetensi dan job deskripsi karyawan (tugas pokok dan fungsi) tidak sesuai dengan kinerja karyawan yang ada di PT. Arghaniaga Pancatunggal. Tujuan penelitian ini adalah untuk mengetahui dan menganalisis seberapa besar pengaruh kompetensi kerja dan job deskripsi terhadap kompetensi karyawan. Penelitian dilakukan dengan mengolah data dari kompetensi, job deskripsi dan kinerja karyawan selama tahun 2018 . Dalam penelitian ini ditemukan hasil data dari pengaruh kompetensi, job deskripsi terhadap kinerja karyawan. Untuk perusahaan pelayaran ini perlu memperhatikan lagi halhal yang mendorong terciptanya kinerja yang baik, perlu penempatan karyawan pada bidang pekerjaan yang sesuai dengan bidang kemampuannya untuk mendorong karyawan mencapai kinerja yang lebih baik, dengan penempatan karyawan pada bidang pekerjaan yang sesuai dengan bidang kemampuannya untuk mendorong karyawan mencapai bidang pekerjaan yang sesuai dengan bidang kemampuannya.
\end{abstract}

Copyright $($ ) 2020, Prosiding Seminar Pelayaran dan Riset Terapan

Kata Kunci: Kompetensi, Job Deskripsi, Kinerja Karyawan

Permalink/DOI : https://doi.org/10.36101/pcsa.v2i1.131

\section{PENDAHULAN}

Di setiap perusahaan maupun instasi pemerintahan, sumber daya manusia memegang peranan yang sangat penting karena sumber daya manusia merupakan elemen dasar yang menggerakan seluruh aktivitas di perusahaan. Keberhasilan dalam mencapai tujuan perusahaan sangat dipengaruhi oleh kontribusi karyawan sebagai unsur manusia di dalamnya. Oleh karena itu setiap perusahaan dituntut untuk dapat mengelola sumber daya manusia yang mereka miliki. Sumber daya manusia yang unggul dan profesional dalam bidangnya sangatlah dibutuhkan guna meningkatkan tujuan atau visi dari sebuah organisasi atau perusahaan.

Sumber daya manusia akan menentukan keberhasilan pelaksanaan kegiatan perusahaan, untuk itu dalam mencapai tujuan organisasi dibutuhkan kompetensi sumber daya manusia yang memadai dalam mendorong kinerja karyawan. Kompetensi sangat diperlukan dalam setiap proses sumber daya manusia. Sumber daya manusia yang memadai dapat dilihat dari kompetensi yang dimiliki setiap karyawan PT. Arghaniaga Pancatunggal Semakin meningkatnya kompetensi SDM, diharapkan akan semakin meningkat pula kinerja organisasi. Semakin banyak kompetensi dipertimbangkan, maka semakin meningkat pula kinerjanya. Perusahaan akan berkembang dan mampu bertahan dalam lingkungan persaingan yang kompetitif apabila didukung oleh pegawai-pegawai yang berkompeten di bidangnya. Kompetensi karyawan yang terdiri dari pengetahuan (knowledge), kemampuan/keterampilan (skill), sikap (attitude) disesuaikan dengan bidang pekerjaan yang dibutuhkan oleh perusahaan sehingga dapat menghasilkan kinerja karyawan yang berprestasi. PT. Arghaniaga Pancatunggal berdiri sejak 11 April 1994 di Cilegon, sesuai dengan Akte Pendirian No. 17 Tanggal 11 April 1994 yang dibuat oleh Notaris Nyonya Endang Sugiharti. Seiring dengan perkembangan perusahaan, pada tanggal 22 Nopember 2004 dan membuka salah satu Kantor Pusat, cabang Bsd (Serpong,Tanggerang Selatan), 
berdasarkan Akte Pendirian: No. 4 Tanggal 22 Nopember 2004 oleh Notaris: Erna Priyono, S.H. dan dikukuhkan oleh Departemen Hukum dan Hak Asasi Manusia, pada tanggal 18 Januari 2005, PT. Arghaniaga Pancatunggal bergerak di bidang Agen Bunker Pertamina yang saat ini memiliki 6 (enam) cabang di seluruh Indonesia yaitu Merak, Jakarta, Surabaya, Balikpapan, Banjarmasin dan Bitung dengan fasilitas 12 (dua belas) unit kapal tanker yang beroperasi dan masih akan terus berkembang lagi mengikuti perkembangan pasar.

PT. Arghaniaga Pancatunggal mempunyai visi menjadi perusahaan pemasok BBM yang terdepan dan memberikan pelayanan bunker BBM yang terbaik bagi kapal pelanggan, serta misi turut berperan serta dalam mendukung kegiatan penyediaan dan penyaluran BBM, di wilayah Indonesia, memberikan dan menjaga standar operasional dan pelayanan yang tinggi kepada pelanggan.

Tujuan dan Manfaat Penelitian

1. Tujuan Penelitian

a. Untuk mengetahui dan menganalisis besarnya pengaruh kompetensi kerja terhadap karyawan pada PT. Arghaniaga Pancatunggal.

b. Untuk mengetahui dan menganalisis besarnya pengaruh job deskripsi terhadap kinerja karyawan pada PT. Arghaniaga Pancatunggal.

c. Untuk mengetahui dan menganalisis besarnya pengaruh kompetensi kerja dan job deskripsi terhadap kinerja karyawan pada PT. Arghaniaga Pancatunggal

2. Manfaat Penelitian

a. Menambah pengetahuan dan wawasan berfikir secara teori manajemen sumber daya manusia pada umumnya, serta khusunya dalam teori kompetensi dan penempatan karyawan terhadap kinerja karyawan.

b. Hasil penelitian ini diharapkan dapat memberikan informasi atau masukan dalam meningkatkan pengetahuan untuk bagian HRD kantor terhadap penempatan karyawan, merekrut karyawan serta pengambilan keputusan serta mampu mengetahui kemungkinan adanya hambatan yang timbul dari permasalahan tersebut. Hasil penelitian ini diharapkan dapat menambah wawasan keilmuan dan sebagai bahan masukan bagi perusahaan untuk mengevaluasi sejauh mana mampu memenuhi perkembangan perusahaan serta hasil ini juga dapat dipergunakan sebagai referensi untuk perkembangan perusahaan selanjutnya.

\section{METODE}

\subsection{Deskripsi Data}

a. Kompetensi $x_{1}$

Pengertian kompetensi oleh Spencer yang dikutip oleh Moeheriono (2014:5) adalah sebagai karakteristik yang mendasari seseorang berkaitan dengan efektivitas kinerja individu dalam pekerjaannya atau karakteristik dasar individu yang memiliki hubungan kausal atau sebagai sebab akibat dengan kriteria yang dijadikan acuan. Menurut Spencer ini, kompetensi terletak pada bagian dalam setiap manusia dan selamanya ada pada kepribadian seseorang yang dapat memprediksikan tingkah laku dan performansi secara luas pada semua situasi dan tugas pekerjaan. b. Job Deskripsi $x_{2}$

Perancangan job description akan

meliputi seluruh jabatan yang ada, sehingga hasil dokumennya menjadi spesifik pada masing-masing jabatan. Stone (2011:29) Job description (uraian jabatan) yaitu dokumen formal organisasi yang berisi ringkasan informasi penting mengenai suatu jabatan untuk memudahkan dalam membedakan jabatan yang satu dengan yang lain dalam suatu organisasi. Uraian jabatan tersebut disusun dalam suatu format yang terstruktur sehingga informasi mudah dipahami oleh setiap pihak yang berkaitan di dalam organisasi,pada hakikatnya, uraian jabatan yaitu bahan baku dasar dalam pengelolaan. c. Kinerja Karyawan

Menurut Sedarmayanti (2011:260), mendifinisikan bahwa, "Kinerja merupakan sistem yang digunakan untuk menilai dan mengetahui apakah seorang karyawan telah melaksanakan pekerjaannya secara keseluruhan, atau merupakan perpaduan dari hasil kerja (apa yang harus dicapai seseorang) dan kompetensi (bagaimana seseorang mencapainya)".

\subsection{Waktu Penelitian}

Penelitian ini dilaksanakan di PT. Arghaniaga Pancatunggal terhitung mulai tanggal 31 Juli 2018 sampai dengan 09 Agustus 2019.

\subsection{Tempat Penelitian}

Penelitian ini dilakukan oleh penulis

di

PT. Arghaniaga Pancatunggal, Jl Rawa Buntu Utara, Tanggerang BSD City .

\subsection{Metode Pendekatan}

Dalam penelitian ini menggunakan metode pendekatan data kuantitatif. Dalam penelitian ini data yang diperoleh dan dianalisis berupa data pada populasi atau sampel tertentu, pengumpulan data menggunakan instrumen penelitian, analisis data bersifat kuantitatif atau statistik dan definisidefinisi pengertian dari referensi buku-buku di 
perpustakaan, dll dengan tujuan untuk menguji hipotesis yang telah ditetapkan.

\subsection{Teknik Pengumpulan Data}

Dalam menyelesaikan penelitian ini penulis mengumpulkan data serta keterangan yang diperlukan guna melengkapi materi penelitian ini dengan menggunakan "Riset Lapangan" dan "Riset Kepustakaan". Penelitian lapangan merupakan penelitian untuk memperoleh data-data yang diperlukan melalui pengamatan dan wawancara secara langsung serta pengambilan data-data primer mengenai perusahaan PT. Arghaniaga Pancatunggal dan Penelitian Kepustakaan merupakan penelitian untuk memperoleh data primer yaitu data-data yang didapat dari membaca buku-buku literatur maupun artikel yang berkaitan dengan kompetensi dan kinerja karyawan. Hal ini dimaksudkan untuk memperoleh gambaran tentang masalah yang akan dibahas serta memperoleh konsep yang diperlukan dalam pembahasan. Dalam penelitian lapangan ini menggunakan teknik sebagai berikut.

a. Observasi

Observasi adalah metode pengumpulan data dimana penelitian mencatat informasi sebagaimana yang mereka saksikan selama penelitian. Penyaksian terhadap peristiwa-peristiwa itu bisa dengan melihat, mendengar, merasakan dan kemudian dicatat secara subyektif. (Gulo, 2002 : 116).

Pada teknik ini, penulis menggunakan penelitian dengan secara langsung dengan mendatangi tempat yang diteliti. Dalam observasi ini peneliti melihat secara langsung di PT. Arghaniaga Pancatunggal. Dimana dalam seksi pengamatan, penulis mengamati Pengaruh Kompetensi dan Job Deskripsi (Tugas Pokok dan Fungsi) Terhadap Kinerja Karyawan.

\section{b. Kuesioner}

Menurut (Sugiyono, 2011:199-203) kuisioner atau angket adalah teknik pengumpulan data yang dilakukan dengan cara memberi seperangkat pertanyaan atau pernyataan tertulis kepada responden untuk dijawabnya. Dengan mengajukan pertanyaan-pertanyaan yang sudah dipersiapkan secara tertulis dengan menyebarkan angket dan disertai dengan alternatif jawaban yang akan diberikan kepada responden.

\subsection{Subjek Penelitian}

Populasi merupakan wilayah atau tempat yang menjadi sumber penelitian. Hal tersebut di perkuat oleh pendapat Sugiyono (2017:80), menyatakan bahwa populasi adalah wilayah generalisasi yang terdiri atas objek atau subjek yang mempunyai kualitas dan karakteristik tertentu yang ditetapkan oleh peneliti untuk dipelajari dan kemudian ditarik kesimpulannya.

Sugiyono (2017:81) yang menyatakan bahwa sampel adalah bagian dari jumlah dan karakteristik yang dimiliki oleh populasi tersebut.

Dalam hal ini, populasi yang diambil oleh penulis dalam penyusunan penelitian ini yaitu adalah seluruh karyawan pada PT. Arghaniaga Pancatunggal yaitu sebanyak 49 orang.

\section{HASIL DAN PEMBAHASAN}

Gambaran umum responden ini bertujuan untuk mengetahui karakteristik-karakteristik dari karyawan yang terpilih menjadi responden berkaitan dengan objek penelitian. Penggolongan terhadap karyawan didasarkan pada masa kerja, dan tingkat pendidikan. Dari penggolongan ini akan diperoleh suatu kesimpulan mengenai keadaan responden. Penggolongan tersebut akan disajikan dalam tabel masing-masing berikut ini:

Tabel 1. Responden Berdasarkan Masa Kerja

\begin{tabular}{|c|c|c|}
\hline $\begin{array}{l}\text { Lama } \\
\text { Kerja }\end{array}$ & $\begin{array}{c}\text { Jumlah } \\
\text { Responden }\end{array}$ & Persentase \\
\hline $\begin{array}{c}<2 \\
\text { Tahun }\end{array}$ & 12 & $36 \%$ \\
\hline $\begin{array}{l}2-4 \\
\text { Tahun }\end{array}$ & 16 & $48 \%$ \\
\hline $\begin{array}{c}5-7 \\
\text { Tahun }\end{array}$ & 3 & $9 \%$ \\
\hline $\begin{array}{c}>7 \\
\text { Tahun }\end{array}$ & 2 & $6 \%$ \\
\hline Total & 33 & $100 \%$ \\
\hline
\end{tabular}

Dari tabel 1 terlihat responden yang menunjukan lama kerja pegawai yang terbesar dalam penelitian ini adalah lebih dari 7 tahun berjumlah 2 orang (6\%), lama kerja pegawai 5 - 7 tahun berjumlah 3 orang (9\%), lama kerja pegawai $2-4$ tahun berjumlah 16 orang (48\%), dan yang kurang dari 2 tahun berjumlah 12 orang (36\%). Sehingga dapat dikatakan bahwa karyawan PT. Arghaniaga Pancatunggal rata-rata 2 sampai 4 tahun.

Tabel 2 Berdasarkan Pendidikan Terakhir

\begin{tabular}{|c|c|c|}
\hline $\begin{array}{c}\text { Pendidikan } \\
\text { Formal }\end{array}$ & $\begin{array}{c}\text { Jumlah } \\
\text { Responden }\end{array}$ & Persentase \\
\hline SLTA & 15 & $45 \%$ \\
\hline Diploma & 1 & $3 \%$ \\
\hline S1 & 16 & $48 \%$ \\
\hline S2 & 1 & $3 \%$ \\
\hline S3 & 0 & $0 \%$ \\
\hline Total & $\mathbf{3 3}$ & $\mathbf{1 0 0 \%}$ \\
\hline Sumber: PT. Arghaniaga Pancatunggal. Data diolah
\end{tabular}


Tabel 2 dalam penelitian responden berdasarkan tingkat pendidikan SLTA sejumlah 15 orang (45\%), tingkat pendidikan Diploma berjumlah 1 orang (3\%), tingkat pendidikan sarjana (S1) berjumlah 16 orang (48\%), tingkat pendidikan sarjana (S2) berjumlahh 1 orang (3\%), dan tidak ada tingkat pendidikan sarjana (S3). Dengan demikian maka dapat disimpulkan bahwa sebagian besar karyawan PT. Arghaniaga Pancatunggal adalah Sarjana (S1).

Uji validitas dilakukan untuk mengetahui apakah alat ukur yang telah disusun benar-benar mampu mengukur apa yang harus diukur. Pengujian validitas tiap butir digunakan analisis item, yaitu mengkorelasikan masing-masing skor tiap butir dengan skor total yang merupakan jumlah tiap skor butir dan nilainya dapat dilihat pada hasil pengolahan menggunakan program SPSS 23.0 pada tabel item total statistic di kolom corrected item-total correlation.

Tabel 3. Validitas Item

\begin{tabular}{|c|c|c|c|c|}
\hline No & Variabel & $\begin{array}{c}\text { Jumlah } \\
\text { Item }\end{array}$ & $\begin{array}{c}\text { Valid } \\
\text { Item }\end{array}$ & Keterangan \\
\hline 1 & $\begin{array}{c}\text { Kompetensi } \\
\text { SDM }\left(\mathrm{X}_{1}\right)\end{array}$ & 15 & 15 & Valid \\
\hline 2 & $\begin{array}{c}\text { Job } \\
\text { Deskripsi } \\
\left(\mathrm{X}_{2}\right)\end{array}$ & 15 & 15 & Valid \\
\hline 3 & $\begin{array}{c}\text { Kinerja } \\
\text { karyawan } \\
(\mathrm{Y})\end{array}$ & 15 & 15 & Valid \\
\hline
\end{tabular}

Sumber: Data primer diolah

Uji reliabilitas bertujuan untuk mengetahui apakah alat pengumpul data pada dasarnya menunjukan ketepatan, keakuratan kestabilan, atau konsistensi alat tersebut dalam mengungkapkan gejala-gejala tertentu dari sekelompok individu, walaupun dilakukan pada waktu yang berbeda. Berdasarkan tingkat reliabilitas, hasil uji koefisien reliabilitas ( $\left.\mathrm{r}_{\text {alpha }}\right)$ terhadap kedua instrumemn variabel yang diuji dapat dirangkum pada tabel di bawah ini :

Tabel 4. Hasil Uji Reliabilitas

\begin{tabular}{|c|c|c|c|c|c|}
\hline No & Variabel & $\mathbf{N}$ & $\begin{array}{c}\text { N of } \\
\text { Item }\end{array}$ & $\begin{array}{c}\text { Cronbach's } \\
\text { Alpha }\end{array}$ & Keterangan \\
\hline $\mathbf{1}$ & $\begin{array}{c}\text { Kompetensi } \\
\text { SDM (X1) }\end{array}$ & 15 & 15 & $\mathbf{0 , 8 6 6}$ & Reliabel/Tinggi \\
\hline $\mathbf{2}$ & $\begin{array}{c}\text { Job Deskripsi } \\
\text { (X2) }\end{array}$ & 15 & 15 & $\mathbf{0 , 8 7 0}$ & Reliabel/Tinggi \\
\hline
\end{tabular}

Berdasarkan tabel rangkuman hasil uji reliabilitas di atas, nilai alpha cronbach untuk kompetensi SDM (X1) adalah 0,866, job deskripsi (X2) adalah 0,870 dan kinerja pegawai (Y) adalah 0,935 . Hal ini berarti bahwa pertanyaan untuk seluruh item pertanyaan adalah reliabel/tinggi untuk variabel kompetensi SDM (X1), job deskripsi (X2) dan untuk varibel kinerja karyawan (Y) seperti yang dikemukakan oleh Sugiyono (2012 : 177), Uji Reliabilitas Uji reliabilitas adalah sejauh mana hasil pengukuran dengan menggunakan objek yang sama akan menghasilkan data yang sama. Apabila korelasi 0,7 maka dikatakan item tersebut memberikan tingkat reliabel yang cukup, sebaliknya apabila nilai korelasi di bawah 0,7 maka dikatakan item tersebut kurang reliabel.

Adapun hasil uji normalitas dengan menggunakan software SPSS 25.0 adalah sebagai berikut:

Tabel 5. Hasil Uji Normalitas (KolmogrovSmirnov test)

One-Sample Kolmogorov-Smirnov Test

\begin{tabular}{|ll|r|}
\hline & & $\begin{array}{r}\text { Unstandardized } \\
\text { Residual }\end{array}$ \\
\hline $\mathrm{N}$ & Mean & 33 \\
Normal & Mean &, 000000 \\
Parameters & Std. &, 46576820 \\
& Deviation &, 116 \\
Most & Absolute &, 073 \\
Extreme & Positive &,- 116 \\
Differences & Negative &, 116 \\
Test Statistic & &, $200^{c, d}$ \\
\hline
\end{tabular}
a. Test distribution is Normal.
b. Calculated from data.
c. Lilliefors Significance Correction.
d. This is a lower bound of the true
significance.

Pada pengujian normalitas mengenai pengaruh kompetensi dan job deskripsi terhadap kinerja karyawan diketahui bahwa nilai unstandardized residual pada uji test Kolmogorov smirnov 
menunjukan nilai sebesar 0,2 atau lebih besar dari alpha 5\% (KS > 0.05). Maka berdasarkan hal ini dapat dinyatakan bahwa data lolos uji normalitas atau data dinyatakan memiliki distribusi data yang normal.

Tabel 6. Hasil Uji Normalitas Variabel

Tests of Normality

\begin{tabular}{|l|r|r|r|}
\hline \multirow{2}{*}{} & \multicolumn{3}{|c|}{ Kolmogorov-Smirnov ${ }^{\mathrm{a}}$} \\
\cline { 2 - 4 } & Statistic & \multicolumn{1}{c|}{ df } & \multicolumn{1}{c|}{ Sig. } \\
\hline X1 2 &, 084 & 33 &, $200^{*}$ \\
Y &, 152 & 33 &, 052 \\
&, 149 & 33 &, 061 \\
\hline
\end{tabular}
*. This is a lower bound of the true
significance.
a. Lilliefors Significance Correction

Berdasarkan data di atas, maka diketahui nilai sig $\mathrm{x}_{1}$ (kompetensi) sebesar 0,2, $\mathrm{x}_{2}$ (job deskripsi) sebesar 0,052, dan kinerja sebesar 0,061 atau dengan kata lain memiliki nilai di atas 0,05 (alpha $5 \%$ maka berdasarkan data tersebut dapat dinyatakan bahwa seluruh data lolos uji normalitas atau data memiliki sebaran yang normal.

a. Kompetensi : Terlihat bahwa pada kolom signifan (Sig) adalah 0,2 atau probabilitas lebih dari 0.05 maka $\mathrm{H}_{1}$ diterima berarti populasi berdistribusi normal.

b. Job Deskripsi : Terlihat bahwa pada kolom signifan (Sig) adalah 0,052 atau probabilitas lebih dari 0.05 maka $\mathrm{H}_{2}$ diterima berarti populasi berdistribusi normal.

c. Kinerja : Terlihat bahwa pada kolom signifan (Sig) adalah 0,061 atau probabilitas lebih dari 0.05 maka $\mathrm{H}_{3}$ diterima berarti populasi berdistribusi normal.

Hasil uji normalitas menunjukkan bahwa data memiliki distribusi normal.

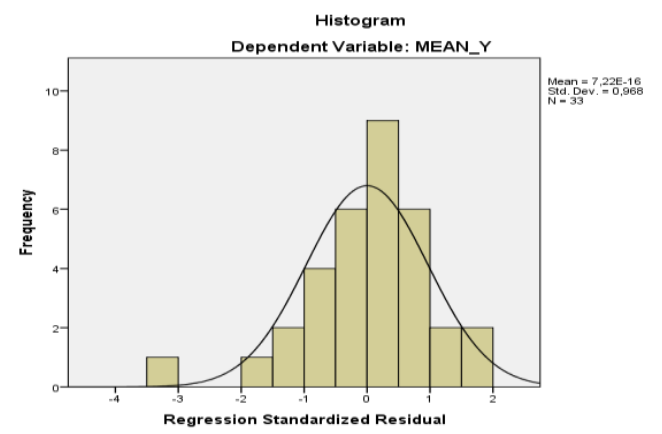

Gambar 1. Kurva Histogram Uji Normalitas

Berdasarkan kurva histogram di atas, dapat dilihat bahwa kurva menyerupai bentuk lonceng yang hampir sempurna dengan kemiringan yang cenderung imbang baik dari sisi kiri maupun dari sisi kanan, hal ini menunjukkan bahwa data telah terdistribusi secara normal. Menurut Ghozali (2011:160). Pendektesian normalitas dapat dilakukan dengan melihat penyebaran data (titik) pada sumbu diagonal dari grafik (Grafik Normal P-P Plot of Regression), yaitu jika data (titik) menyebar di sekitar garis diagonal dan mengikuti arah garis diagonal, hal ini menunjukkan data yang telah terdistribusi normal.

Berikut ini dilampirkan grafik scatterplot untuk menganalisis apakah terjadi normalitas dengan mengamati penyebaran titik-titik pada gambar.

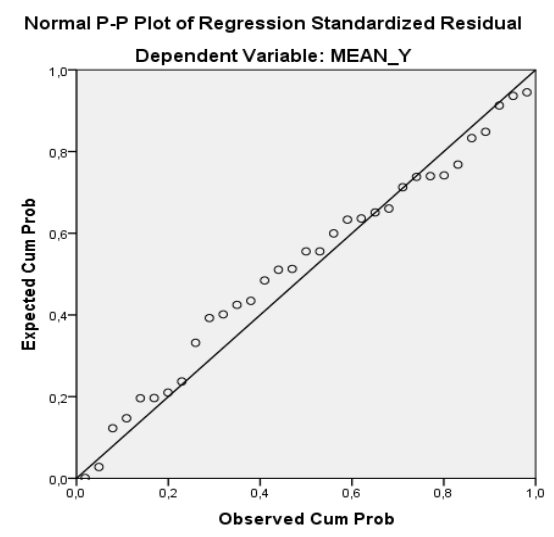

Gambar 2. Grafik Normal P-P Plot of Regression Grafik Normal P-P Plot of Regression di atas meperlihatkan titik-titik menyebar berhimpitan di sekitar diagonal dan ini menunjukkan data dalam model regresi berdistribusi normal. Karena secara keseluruhan data telah terdistribusi secara normal.

Uji multikolinieritas dilakukan dengan melihat nilai VIF dari variabel bebas. Hasil pengujian menunjukkan bahwa seluruh variabel bebas tidak memiliki gejala multikolinieritas. Hasilnya ditunjukkan oleh tabel di bawah ini.

Tabel 7. Hasil Uji Multikolinieritas

\section{Coefficients $^{\mathrm{a}}$}

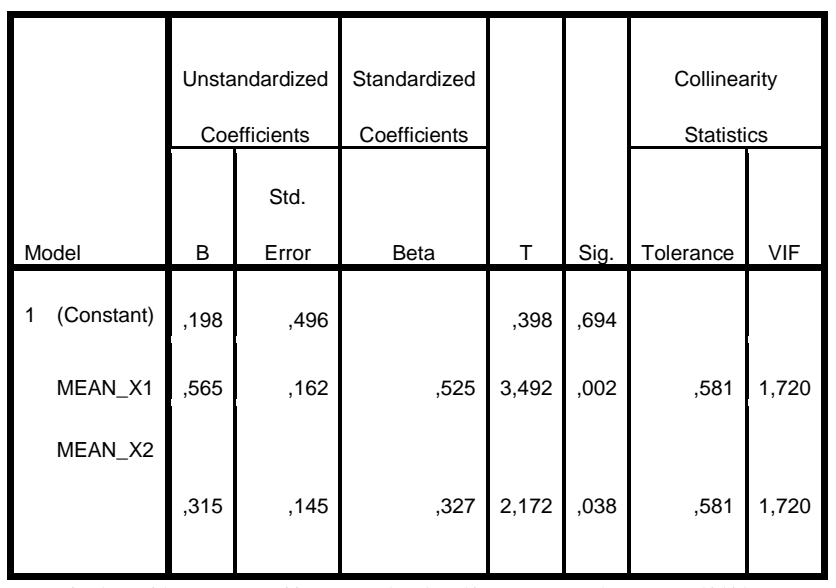

Dari hasil pengujian tabel di atas, dapat dilihat bahwa angka nilai VIF $1,720<10$, dan nilai Tolerance $0,581>0,1$ ini artinya data lolos uji multikolinearitas. Ini mengindikasikan bahwa tidak terjadi multikolinieritas diantara variabel independen dalam penelitian.

Uji Heterokedastisitas bertujuan untuk 
melihat apakah dalam model regresi terjadi ketidaksamaan variabel dari residual satu pengamatan ke pengamatan lain. Hasil dari uji heteroskedastisitas dengan grafik Scatterplot, di tunjukkan sebagai berikut :

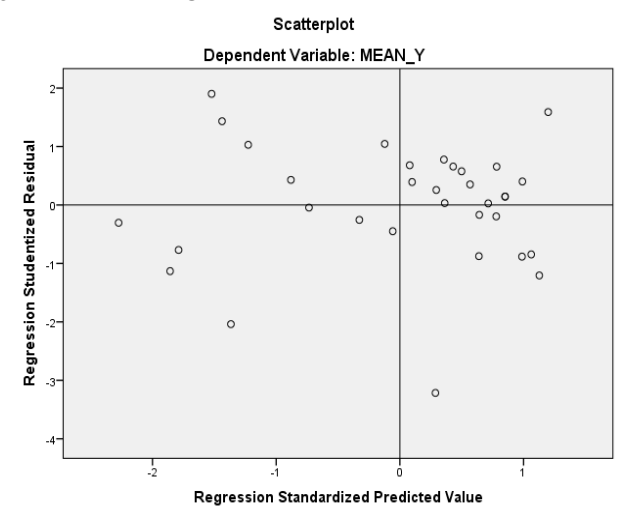

Gambar 3. Grafik Scatterplot Uji

Heteroskedastisitas

Grafik Scatterplot di atas memperlihatkan titiktitik menyebar dan tidak membentuk pola tertentu yang jelas. Sehingga dapat disimpulkan bahwa tidak terjadi masalah heteroskedastisitas. Untuk melihat apakah dalam suatu model regresi linear ada korelasi antara kesalahan pengganggu pada periode $\mathrm{t}$ dengan kesalahan pengganggu pada periode $\mathrm{t}-1$ (sebelumnya). Uji autokorelasi dilakukan dengan melihat nilai uji Durbin Watson, pada model penelitian ini jumlah $n$ adalah 33 dan jumlah variabelnya adalah 3 .

Kriteria penialaian uji autokorelasi :

$\mathrm{dU}<\mathrm{d}<4-\mathrm{dU} \rightarrow$ ho diterima tidak ada auto

korelasi

$\mathrm{d}<\mathrm{dL}$ atau $\mathrm{d}>4$-dL maka ho ditolak ada

autokoreelasi

$\mathrm{dL}<\mathrm{d}<\mathrm{dL}$ atau 4-dU $<\mathrm{d}<4-\mathrm{dL}$ maka tidak ada kesimpulan.

Diketahui: $\mathrm{d}=1,866$

Maka pada nilai sig 0,05 (alpha 5\%), $\mathrm{n}=33, \mathrm{~K}-2$ Diketahui :

$$
\begin{array}{ll}
\mathrm{dL} & =1,114 \text { dan } \mathrm{dU}=1,358 \\
4-\mathrm{dU} & =4-1,358=2,642 \\
4-\mathrm{dL} & =4-1,114=2,886
\end{array}
$$

Kesimpulan $\rightarrow$ dU $(1,358)<\mathrm{d}(1,866)<4-\mathrm{dU}$ $(2,642) \rightarrow$ ho diterima tidak ada auto korelasi.

Perhitungan korelasi hubungan antara variabel $X_{1}$, variabel $X_{2}$ dan variabel $Y$. Untuk memastikan apakah ketiga variabel tersebut memiliki hubungan atau tidak, maka dapat di uji dengan analisis statistik. Dalam penelitian ini penulis akan menjelaskan tentang kompetensi dan job deskripsi terhadap kompetensi di PT. Arghaniaga Pancatunggal, selanjutnya seluruh data yang telah lolos uji asumsi klasik (normalitas, multikolinearitas, heteroskesdastisitas, autokorelasi) uji validitas dan reliabilitas, akan dilakukan pengujian pada uji regresi berganda, dengan metode sebagai berikut :

$\begin{array}{ll}\mathrm{n} & =33 \\ \sum \mathrm{x} 1 & =126,286 \\ \sum \mathrm{x} 2 & =120,375 \\ \sum \mathrm{Y} & =115,800 \\ \sum X_{1 i}^{2} & =498,490 \\ \sum X_{2 i}^{2} & =457,984 \\ \sum \mathrm{Y}^{2} & =423,933 \\ \sum \mathrm{X}_{1 i} X_{2 i} & =471,625 \\ \sum \mathrm{X}_{1 i} \mathrm{Y}_{i} & =455,200 \\ \sum \mathrm{X}_{2 i} \mathrm{Y}_{i} & =434,558 \\ \sum(\mathrm{Y}-\overline{\mathrm{Y}})^{2} & =17,581\end{array}$

Matrix Regresi Berganda

$\left[\begin{array}{ccc}\mathrm{n} & \sum \mathrm{X}_{1 i} & \sum \mathrm{X}_{2 i} \\ \sum \mathrm{X}_{1 i} & \sum \mathrm{X}_{1 i}^{2} & \sum \mathrm{X}_{1 i} X_{2 i} \\ \sum \mathrm{X}_{2 i} & \sum \mathrm{X}_{2 i} \mathrm{X}_{1 i} & \sum X_{2 i}^{2}\end{array}\right]\left[\begin{array}{c}b_{0} \\ b_{1} \\ b_{2}\end{array}\right]=\left[\begin{array}{c}\sum \mathrm{Y}_{i} \\ \sum \mathrm{X}_{11} \mathrm{Y}_{i} \\ \sum \mathrm{X}_{2 i} \mathrm{Y}_{i}\end{array}\right] \rightarrow \underline{\mathrm{Ab}}=\underline{\mathrm{H}}$

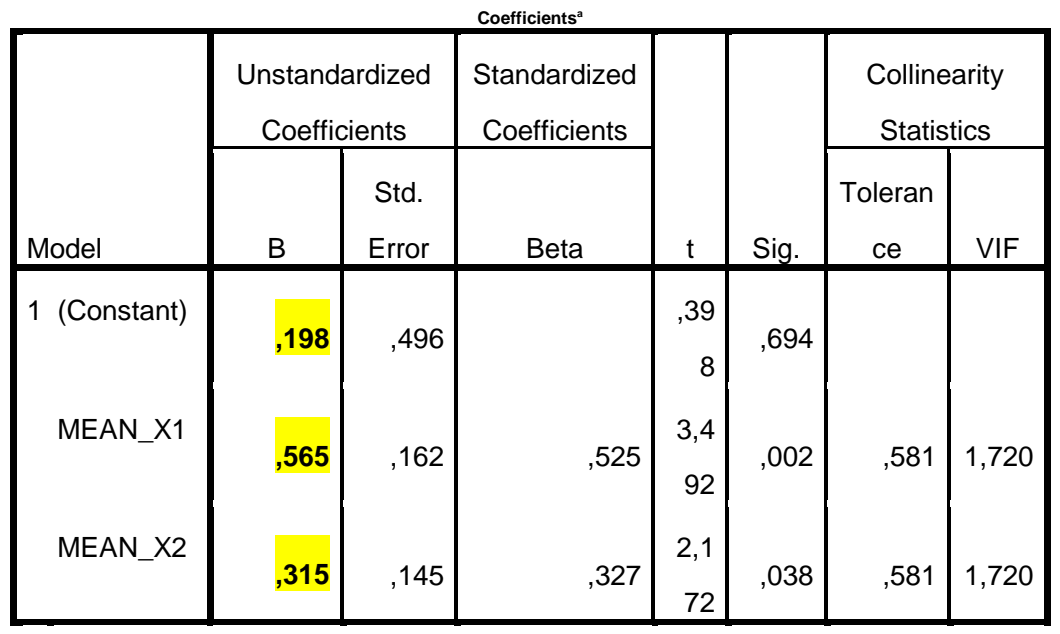

a. Dependent Variable: MEAN_Y $\underline{b}=\underline{\mathrm{A}^{-1}} \underline{\mathrm{H}}$

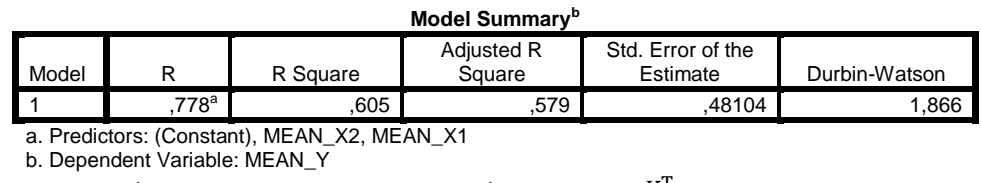

$$
\begin{aligned}
& A^{-1} \frac{1}{\operatorname{Det}(\mathrm{A})}=\operatorname{Adj}(\underline{\mathrm{A}})=\operatorname{dimana}:=\frac{1}{|\mathrm{~A}|} \operatorname{Adj}(\underline{\mathrm{A}})=\frac{\mathrm{K}^{\mathrm{T}}}{|\mathrm{A}|} \\
& \mathrm{K}=\text { Matriks Ko Faktor, } \mathrm{K}^{\mathrm{T}}=\operatorname{Transpos} \underline{\mathrm{K}} \\
& K=\left[\begin{array}{lll}
K_{11} & K_{12} & K_{13} \\
K_{21} & K_{22} & K_{23} \\
K_{31} & K_{32} & K_{33}
\end{array}\right] \\
& \operatorname{Det}(\mathrm{A})=\mathrm{a}_{11} * \mathrm{~K}_{11}+\mathrm{a}_{12} * \mathrm{~K}_{12}+\mathrm{a}_{13} * \mathrm{~K}_{13}
\end{aligned}
$$$$
\left[\begin{array}{ccc}
33 & 126,286 & 120,375 \\
126,286 & 498,490 & 471,625 \\
120,375 & 471,625 & 457,984
\end{array}\right] \quad\left[\begin{array}{l}
b_{0} \\
b_{1} \\
b_{2}
\end{array}\right]=\left[\begin{array}{c}
115,800 \\
55,200 \\
434,558
\end{array}\right]
$$ 
$K=\left[\begin{array}{ccc}5.870,397 & -1.065,025 & -446,209 \\ -1.065,025 & 623,344 & -361,982 \\ -446,209 & -361,982 & 502,08\end{array}\right]$

$\operatorname{Det}(\mathrm{A})=\mathrm{a}_{11} * \mathrm{~K}_{11}+\mathrm{a}_{12} * \mathrm{~K}_{12}+\mathrm{a}_{13} * \mathrm{~K}_{13}$

$\operatorname{Det}(\mathrm{A})=\{(33) *(5.870,397)+(126,286) *(-1.065,025)+$ $(120,375) *(-446,209)\}$

$\operatorname{Det}(\mathrm{A})=5.513,284$

$\frac{1}{\operatorname{Det}(\mathrm{A})}\left[\begin{array}{lll}\mathrm{K}_{11} & \mathrm{~K}_{12} & \mathrm{~K}_{13} \\ \mathrm{~K}_{21} & \mathrm{~K}_{22} & \mathrm{~K}_{23} \\ \mathrm{~K}_{31} & \mathrm{~K}_{32} & \mathrm{~K}_{33}\end{array}\right]=$ $\frac{1}{5.513,284}\left[\begin{array}{ccc}5.870,397 & -1.065,025 & -446,209 \\ -1.065,025 & 623,344 & -361,982 \\ -446,209 & -361,982 & 502,08\end{array}\right]$

$\underline{\mathrm{b}}=\left(\underline{X^{\mathrm{T}}} \underline{\mathrm{X}}\right)^{-1} \mathrm{X}^{\mathrm{T}} \mathrm{Y}=\mathrm{A}^{-1} \mathrm{X}^{\mathrm{T}} \mathrm{Y}$

$\left[\begin{array}{l}b_{0} \\ b_{1} \\ b_{2}\end{array}\right]=\frac{1}{5.513,284}\left[\begin{array}{ccc}5.870,397 & -1.065,025 & -446,209 \\ -1.065,025 & 623,344 & -361,982 \\ -446,209 & -361,982 & 502,08\end{array}\right]\left[\begin{array}{c}115,800 \\ 55,200 \\ 434,558\end{array}\right]$

$\mathrm{b}_{0}=\frac{1}{5.513,284}\{(5.870,397) *(115,800)+(-1.065,025) *$ $(55,200)+(-446,209) *(434,558)\}=\mathbf{0 , 1 9 8}$

$\mathrm{b}_{1}=\frac{1}{5.513,284}\{(-1.065,025) *(115,800)+(623,344) *$ $(55,200)+(-361,982) *(434,558)\}=\mathbf{0 , 5 6 5}$

$\mathrm{b}_{2}=\frac{1}{5.513,284}\{(-446,209) *(115,800)+(-361,982) *$

$(55,200)+(502,08) *(434,558)\}=\mathbf{0 , 3 1 5}$

Sehingga Persamaan Statistiknya menjadi :

$\mathrm{Y}=\mathrm{b}_{0}+\mathrm{b}_{1} \mathrm{X}_{1}+\mathrm{b}_{2} \mathrm{X}_{2}$

$\mathrm{Y}=0,198+0,565+0,315$

Jika nilai kompetensi dan job deskripsi nol, maka nilai kinerja sebesar 0,198. Jika terjadi peningkatan pada nilai kompetensi sebesar 1 satuan, maka nilai kinerja meningkat sebesar 0,565, sedangkan jika terjadi peningkatan job deskripsi sebesar 1 satuan, maka kinerja meningkat sebesar 0,315. Berdasarkan hal ini disimpulkan bahwa kompetensi dan job deskripsi berpengaruh positif terhadap peningkatan kinerja.

\section{Koefisien Korelasi}

Analisis korelasi ganda digunakan untuk mengetahui besarnya atau kekuatan hubungan antara seluruh variabel bebas terhadap variabel terikat secara bersamaan. Menurut Sugiyono (2013:256) koefisien korelasi, untuk mengetahui bagaimana hubungan kompetensi dan job deskripsi terhadap kinerja maka dilakukan uji analisis korelasi. Berdasarkan data hasil penelitian yang diperoleh dari responden, maka jika diterapkan dalam rumus akan diperoleh hasil sebagai berikut :

$$
\begin{aligned}
\mathrm{R}^{2}=\frac{\mathrm{b}_{1} \sum \mathrm{X}_{1} \mathrm{Y}+\mathrm{b}_{2} \sum \mathrm{X}_{2} \mathrm{Y}}{\sum \mathrm{Y}^{2}} & \rightarrow \sum \mathrm{Y}^{2}=\sum(\mathrm{Y}-\overline{\mathrm{Y}})^{2}=17,581 \\
\sum \mathrm{X}_{1} \mathrm{Y} & =\left(\sum \mathrm{X}_{1}-\overline{\mathrm{X}}\right)(\mathrm{Y}-\overline{\mathrm{Y}}) \\
& =\sum \mathrm{X}_{1} \mathrm{Y}-\sum \mathrm{X}_{1} \sum \mathrm{Y} / \mathrm{n} \\
& =455,200-\frac{126,286 * 115,800}{33}=12,051 \\
\sum \mathrm{X}_{2} \mathrm{Y} & =\sum \mathrm{X}_{2} \mathrm{Y}-\sum \mathrm{X}_{2} \sum \mathrm{Y} / \mathrm{n} \\
& =434,558-\frac{120,375 * 115,800}{33}=12,151
\end{aligned}
$$

$\mathrm{R}^{2}=\frac{(0,565) *(12,051)+(0,315) *(12,151)}{17,581}$

$\mathrm{R}^{2}=0,605128$

Koefisien Korelasi

$\mathrm{r}=\sqrt{R^{2}}$

$r=\sqrt{0,605128} \quad=0,778$

Dari hasil perhitungan di atas dapat diketahui nilai $\mathrm{r}=0,778$ berarti kompetensi dan Job Deskripsi mempunyai hubungan yang kuat dengan kinerja dan bersifat positif, artinya jika kompetensi dan Job Deskripsi ditingkatkan maka kinerja akan meningka

\section{Analisis Koefesien Determinasi}

Analisis Koefisien Determinasi Menurut Imam Ghazali (2013:97) Koefisien determinasi $\left(\mathrm{R}^{2}\right)$ pada intinya mengukur seberapa jauh kemampuan model dalam menerangkan variasi variabel 105 independen. Nilai koefisien determinasi adalah nol dan satu. Nilai $R^{2}$ yang kecil berarti kemampuan variabel-variabel independen dalam menjelaskan variasi variabel dependen amat terbataas. Nilai yang mendekati satu berarti variabelvariabel independen memberikan hampir semua informasi yang dibutuhkan untuk memprediksi variasi variabel dependen. Koefisien Determinasi $(\mathrm{Kd})$ dihitung dengan rumus sebagai berikut: $K d=r 2 x 100 \%$ Keterangan: $\mathrm{Kd}=$ 
Koefisien determinasi r $2=$ Koefisien kuadrat korelasi ganda ( Coefficient Of Determination ), untuk mengukur seberapa kuat hubungan variabel $\mathrm{x}_{1}, \mathrm{x}_{2}$ dan y digunakan Rumus Koefisien penentu sebagai berikut :

$$
\begin{aligned}
& \text { Koefisien Determinasi } \\
& \mathrm{Kd}=\mathrm{r}^{2} \times 100 \% \\
& \mathrm{Kd}=0,778^{2} \times 100 \%=60,5 \%
\end{aligned}
$$

Pengaruh variabel bebas (kompetensi SDM dan Job Deskripsi) terhadap variabel terikat (kinerja karyawan) adalah sebesar $60,5 \%$, sedangkan sisanya $39,5 \%$ dipengaruhi oleh variabel yang lain.

\section{Uji F (Signifikan Simultan)}

Uji F (uji simultan) adalah untuk melihat apakah variabel kompetensi dan job deskripsi secara bersama-sama mempunyai pengaruh yang signifikan terhadap variabel kinerja. Melalui uji statistik dengan langkah-langkah sebagai berikut:

Uji F :

$\mathrm{F}_{0} \quad=\frac{R^{2}(n-k-1)}{k\left(1-R^{2}\right)} \rightarrow=\frac{0,605128(33-k 2-1)}{2(1-0,605128)}=22,987$

$\mathrm{F}$ tabel $=(\mathrm{df} 1=\mathrm{k}-1=3-1=2, \mathrm{df} 2=\mathrm{n}-\mathrm{k}=33-3=30)=3,32$

Berdasarkan hasil tersebut diketahui Fhitung 22,987 > Ftabel 3,32, ini artinya $\mathrm{h}_{0}$ ditolak. Variabel kompetensi dan job deskripsi secara bersama2 berpengaruh signifikan terhadap kinerja.

\section{Uji t (Signifikan Parsial)}

Pengolahan data akan dilakukan dengan Dilakukan dengan cara membandingkan nilai thitung dengan $t_{\text {tabel }}$. Untuk mengetahui $t_{\text {hitung }}$ digunakan rumus sebagai berikut :

Uji thitung :

$\mathrm{t}_{1}=\frac{b_{1}}{s_{b 1}}=\frac{0,565}{? ? ? ?}=$ maka $\rightarrow \underline{\mathrm{e}}^{\mathrm{T}} \underline{\mathrm{e}}=\sum e_{i}^{2}=\underline{\mathrm{Y}}^{\mathrm{T}} \underline{\mathrm{Y}}-\underline{\mathrm{b}}^{\mathrm{T}} \underline{\mathrm{X}}^{\mathrm{T}} \underline{\mathrm{Y}}$

$=\sum Y_{i}^{2}-b_{o} \sum \mathrm{Y}_{i}-b_{1} \sum \mathrm{X}_{1 i} \sum \mathrm{Y}_{i}-b_{2} \sum \mathrm{X}_{2 i} \sum \mathrm{Y}_{i}$

$=423,933-(0,198 * 115,8)-(0,565 * 455,2)-$

$(0,315 * 434,558)$

$$
\begin{aligned}
& =423,933-22,928-257,188-136,886 \\
& =6,931
\end{aligned}
$$

$$
\begin{aligned}
& S_{e}^{2}=\frac{e^{T} e}{n-k-1}=\frac{S_{e}^{2}}{33-2-1}==\frac{6,931}{30}=0,231 \\
& \underline{\mathrm{D}}=\left(\underline{\mathrm{X}}^{\mathrm{T}} \underline{\mathrm{X}}^{-1}=\underline{\mathrm{A}}^{-1}=\frac{1}{5.513,284}\left[\begin{array}{ccc}
5.870,397 & -1.065,025 & -446,209 \\
-1.065,025 & 623,344 & -361,982 \\
-446,209 & -361,982 & 502,08
\end{array}\right]\right. \\
& S_{b 0}^{2}=S_{e}^{2} d_{11}=\frac{0,231}{5.513,284}(5.870,397)=0,246 \\
& S_{\mathrm{b} 0}=\sqrt{S_{b 0}^{2}}=0,496 \\
& S_{b 1}^{2}=S_{e}^{2} d_{22}=\frac{0,231}{5.513,284}(623,344)=0,0261 \\
& \text { Tabel } 4.13
\end{aligned}
$$

Hasil Uji Autokorelasi (Durbin-Watson)

\begin{tabular}{|l|c|r|r|r|r|}
\hline \multicolumn{7}{|c|}{ Model Summary } \\
Model & $\mathrm{R}$ & $\mathrm{R}$ Square & $\begin{array}{c}\text { Adjusted R } \\
\text { Square }\end{array}$ & $\begin{array}{c}\text { Std. Error of the } \\
\text { Estimate }\end{array}$ & $\begin{array}{c}\text { Durbin- } \\
\text { Watson }\end{array}$ \\
\hline 1 &, $778^{\mathrm{a}}$ &, 605 &, 579 &, 48104 & 1,866 \\
\hline
\end{tabular}

a. Predictors: (Constant), MEAN_X2, MEAN_X1

b. Dependent Variable: MEAN_Y

$\mathrm{S}_{\mathrm{b} 1}=\sqrt{S_{b 1}^{2}}=0,162$

$S_{b 2}^{2}=S_{e}^{2} d_{33}=\frac{0,231}{5.513,284}(502,08)=0,0210$

$\mathrm{S}_{\mathrm{b} 2}=\sqrt{S_{b 2}^{2}}=0,145$

$\mathrm{t}_{1}=\frac{b_{1}}{s_{b 1}}=\frac{0,565}{0,162}=3,489$

$\mathrm{t}_{2}=\frac{b_{2}}{s_{b 2}}=\frac{0,315}{0,145}=2,172$

Sedangkan hasil dari tabel :

$$
\begin{aligned}
& t_{\text {tabel }}=(\alpha=0,05 ; d f=n-2) \\
& t_{\text {tabel }}=(\alpha=0,05 ; d f=33-2) \\
& t_{\text {tabel }}=(\alpha=0,05 ; d f=31) \\
& t_{\text {tabel }}=2,04227
\end{aligned}
$$

$\mathrm{t}_{1 \text { hitung }}$ sebesar 3,489 $>\mathrm{t}$ tabel 2,04227 $(\mathrm{df}=\mathrm{n}-\mathrm{k}$ $1=33-2-1$ ) maka disimpulkan $\mathrm{h}_{01}$ ditolak, maka kompetensi berpengaruh positif dan signifikan terhadap peningkatan kinerja

$\mathrm{t}_{2 \text { hitung }}$ sebesar 2,172 $>\mathrm{t}$ tabel 2,04227 $(\mathrm{df}=\mathrm{n}-\mathrm{k}$ $1=33-2-1)$ maka disimpulkan $\mathrm{h}_{02}$ ditolak, maka 
job deskripsi berpengaruh positif dan signifikan terhadap peningkatan kinerja.

\section{KESIMPULAN}

Berdasarkan hasil penelitian yang dilakukan pada PT. Arghaniaga Pancatunggal maka penulis menarik kesimpulan:

1. Berdasarkan tabel rekapitulasi variabel $X_{1}$ menunjukkan bahwa kompetensi sumber daya manusia pada PT. Arghaniaga Pancatunggal berada pada kategori tinggi dengan persentase $73,45 \%$ dan variabel $\mathrm{X}_{2}$ menunjukan bahwa job deskripsi dengan persentase 70,14\%, sedangkan untuk variabel $\mathrm{Y}$ menunjukkan bahwa kinerja karyawan PT. Arghaniaga Pancatunggal juga berada pada kategori tinggi dengan presentase $70,18 \%$. Hal ini menunjukkan bahwa kinerja karyawan pada PT. Arghaniaga Pancatunggal sudah berada pada kategori yang baik dan memuaskan.

2. Dari hasil analisis mengenai hubungan kompetensi sumber daya manusia $\left(\mathrm{X}_{1}\right)$ dan job deskripsi $\left(\mathrm{X}_{2)}\right.$ terhadap kinerja karyawan (Y) dengan menggunakan analisis koefisiensi korelasi $(r)=0,778$. Hal ini membuktikan bahwa kompetensi sumber daya manusia dan job deskripsi mempunyai pengaruh yang sangat kuat dan signifikan terhadap kinerja karyawan. Dan diperoleh angka $\mathrm{t}_{\text {hitung }}$ sebesar $(3,489)>t$ tabel $(2,04227)$ dan $t_{2 \text { hitung }}$ sebesar $(2,172)>t$ tabel $(2,04227)$ sehingga $\mathrm{H}_{01}$ dan $\mathrm{H}_{02}$ ditolak sedangkan $\mathrm{Ho}$ diterima, berarti ada hubungan yang signifikan antara variabel $\mathrm{X}_{1}$ (kompetensi $\mathrm{SDM})$ dan $\mathrm{X}_{2}$ (job deskripsi) dengan variabel Y (kinerja karyawan).

3. Dengan nilai $\mathbf{r}^{2}=60,5$ menunjukan bahwa pengaruh kompetensi sumber daya manusia dan job deskripsi sangat kuat terhadap kinerja karyawan sebesar $60,5 \%$, sisanya $39,5 \%$ disebabkan oleh variabel lain yang tidak diteliti oleh penulis.

\section{DAFTAR PUSTAKA}

[1] Aprianto, Brian \& Jacob, A.F. (2013). Pedoman Lengkap Profeisonal SDM Indonesia.Jakarta : PPM Management.

[2] Anwar Prabu Mangkunegara (2010). Manajemen Sumber daya Manusia perusahaan. Bandung : PT Remaja Rosdakarya.

[3] Dessler, Gary. 2010 .Manajemen Sumber Daya Manusia (edisi kesepuluh). Jakarta Barat: PT Indeks.
[4] Moeheriono, 2014, Pengukuran Kinerja Berbasis Kompetensi Edisi Revisi, Jakarta: PT Raja Grafindo Persada

[5] Riniwati, Harsuko. 2011. "Mendongkrak Motivasi dan Kinerja: Pendekatan Pemberdayaan SDM". UB Press: Malang.

[6] Santoso, Yussy, dan Ronnie R.Rasman.2015.Organization Design and Job Analysis.Jakarta: PT Elex Media Komputindo.

[7] 2010. "Metode Penelitian Bisnis (Pendekatan Kuantitatif, Kualitatif dan R\&D)". Alfabeta: Bandung.

[8] Baker, Chris. Cultural Studies, Theory and Practice, diterjemahkan: Nurhadi, Cultural Studies, Teori\&Praktik (2016). Bantul: KreasiWacana.

[9] Wibowo, 2016. Manajemen Kinerja, Edisi Kelima, PT. Raja grafindo persada Jakarta14240

[10] Veitzhal Rivai. (2011). Manajemen Sumber Daya Manusia Untuk Perusahaan Dari Teori Ke Praktek. PT. RAJA GRAFINDO PERSADA, Jakarta

[11] Faustyna. (2014) Pengaruh Kompetensi dan Komitmen Pada Tugas Terhadap Kinerja Karyawan Pada Hotel Dharam Deli Medan. MANAJEMEN \& BISNIS, Vol 14, No.1, April 2014, HL 49-63

[12] Wati, Kadek Desiana, Nyoman Trisna Herawati, dan Ni Kadeak Sirnawati. 2014. Pengaruh Kompetensi SDM, Penerapan SAP, Dan Sistem Akuntansi Laporan Keuangan Daerah. Singaraja:e-S1 Ak Universitas Pendidikan. Vol. 2,No.1 